\title{
Prevention of hepatitis with immunoglobulin
}

\author{
DANIEL ReID \\ Communicable Diseases Unit, \\ Ruchill Hospital, Glasgow, N.W
}

\begin{abstract}
Summary
Immunoglobulin appears to be effective in preventing the clinical features of infectious hepatitis among contacts of the disease provided it is given before the later stages of the incubation period. A single dose of $750 \mathrm{mg}$ gives protection for a period of up to 7 months.

The evidence of the value of immunoglobulin for contacts of serum hepatitis is conflicting.
\end{abstract}

\section{Introduction}

Human normal immunoglobulin (formerly known as gammaglobulin) has been given for many years to persons who have come into contact with infectious hepatitis, or to those liable to come into contact with the disease, in the hope of preventing infection.

Many studies of the protection conferred by American immunoglobulin have been made following the observations of its efficacy by Stokes \& Neefe in 1945. Notable among these were the investigations carried out at the Willowbrook State School and described by Krugman (1963). Immunoglobulin was given to 635 children newly admitted to this mental institution where infectious hepatitis was endemic; during the first 6 months after inoculation only one case of jaundice occurred in this treated group compared with thirty-one cases in a control group of untreated children.

These studies left little doubt that the American product gives a large degree of protection against the clinical manifestations of the disease. However, as far as British immunoglobulin was concerned, it could not be assumed that a similar protective effect would be obtained from material prepared in the United Kingdom where there are no commercial sources of blood and where persons with a history of jaundice are not accepted as blood donors. Because this selection might affect the antibody content of the British product two investigations have been undertaken by the Epidemiological Research Laboratory of the Public Health Laboratory Service to determine the protective effect of the British product and to measure the period of protection.

\section{Protective effect of immunoglobulin}

The investigation to determine if British immunoglobulin conferred protection was completed in 1968
(Public Health Laboratory Service, 1968) and involved Medical Officers of Health from many parts of the United Kingdom, doctors in charge of schools and institutions, and physicians responsible for the care of those contacts who subsequently developed hepatitis.

The Medical Officer of Health arranged to have notified to him any case or cases of infectious hepatitis which occurred in a school or other institution. Contacts of these index cases were allocated by an effective random method to receive an injection of immunoglobulin or remain uninoculated to act as controls. The immunoglobulin was taken from reserved batches and the dose used was $250 \mathrm{mg}$ (i.e. $1.7 \mathrm{ml}$ of a $16 \%$ solution) for those under 10 years of age and $500 \mathrm{mg}$ for older contacts. Both groups were observed for 6 months after the date of occurrence of the last case of infectious hepatitis. A total of 2050 contacts were inoculatedo and there were 2053 controls.

During the follow-up period eighteen cases of infectious hepatitis occurred among those given immunoglobulin and sixty cases were reported among the controls (Table 1). However, if the cases that occurred during the first 2 weeks after injection were excluded (because they were probably incubating the disease when injected) only six inoculated persons developed the disease compared with fortysix persons in the control group.

This investigation demonstrates therefore, that immunoglobulin of British origin is an effective measure against the development of the clinical manifestations of infectious hepatitis among contacts. However, although suppressing the overt features of the disease, there is evidence (Ward \& Krugman, 1962) that immunoglobulin does not prevent infection as judged by liver function tests and inoculated contacts should therefore still be regarded as being potentially infectious.

\section{Period of protection}

To determine the length of time a single dose of immunoglobulin is protective against infectious hepatitis a retrospective survey involving members of Voluntary Service Overseas (VSO) was undertaken (Pollock \& Reid, 1969). Each year members of this organisation, who are usually young adults, leave the United Kingdom for periods of up to 2 years to 
TABLE 1. Cases of infectious hepatitis according to weeks after start of trial

\begin{tabular}{ccccccccccc}
\hline \multirow{1}{*}{ Group } & \multicolumn{7}{c}{ Weeks } & Total \\
\cline { 2 - 8 } & $<1$ & 1 & 2 & 3 & 4 & 5 & 6 & 7 & $8+$ & 18 \\
\hline $\begin{array}{c}\text { Given } \\
\text { immunoglobulin }\end{array}$ & 5 & 7 & 2 & 0 & 2 & 0 & 0 & 1 & 1 & 18 \\
$\begin{array}{c}\text { Not given } \\
\text { immunoglobulin }\end{array}$ & 6 & 8 & 5 & 7 & 8 & 4 & 4 & 5 & 13 & 60 \\
\hline
\end{tabular}

TABLE 2. Cases of infectious hepatitis according to months after leaving the United Kingdom

\begin{tabular}{|c|c|c|c|c|c|c|c|c|c|c|c|c|c|c|c|c|c|c|c|c|}
\hline \multirow{2}{*}{ Group } & \multicolumn{19}{|c|}{ Months } & \multirow{2}{*}{ Total } \\
\hline & 1 & 2 & 3 & 4 & 5 & 6 & 7 & 8 & 9 & 10 & 11 & 12 & 13 & 14 & 15 & 16 & 17 & 18 & 19 & \\
\hline $\begin{array}{l}\text { Given } \\
\text { immunoglobulin } \\
\text { Not given }\end{array}$ & 1 & & & & & & & 1 & 6 & 3 & 3 & 8 & 1 & & & 1 & & & 1 & 25 \\
\hline immunoglobulin & & 2 & 1 & 1 & 2 & 1 & 1 & 5 & 3 & 4 & & & & & & & & & & 20 \\
\hline
\end{tabular}

work in countries where the chance of acquiring hepatitis would be expected to be higher than in Britain.

Since July 1965 a single dose of $750 \mathrm{mg}(5 \cdot 1 \mathrm{ml})$ of immunoglobulin has been given to each member about a week before departure from the United Kingdom and the dose has not been repeated during their stay overseas. It was therefore possible to compare the frequency of infectious hepatitis among the inoculated members with that in those who went abroad during the year before immunoglobulin was made available. Of the inoculated members of VSO only one case of infectious hepatitis occurred during the first 7 months after receiving immunoglobulin (Table 2) and he became ill within a week of inoculation. After the seventh month, however, cases began to appear in the inoculated group. In contrast, among those who were not given immunoglobulin, infectious hepatitis began to occur during the second month abroad. Thus a single dose of $750 \mathrm{mg}$ appears to be effective for a period of up to 7 months after inoculation.

Immunoglobulin for the prevention of serum hepatitis

The evidence of the value of immunoglobulin for the prevention of serum hepatitis is conflicting. Grossman, Stewart \& Stokes (1945) reported that $11.5 \%$ of battle casualties who had been given blood transfusions became jaundiced compared with only $2.9 \%$ of those who had also received $10 \mathrm{ml}$ of immunoglobulin.

More recently, however, studies by Krugman \& Giles (1970) have cast doubt on the usefulness of immunoglobulin for contacts of serum hepatitis. Mixtures of immunoglobulin and serum from patients suffering from serum hepatitis were given to fourteen children and ten developed the disease (Table 3). Of eight other children who were given
TABLE 3. Effect of immunoglobulin on the infectivity of IH and SH viruses* (Krugman \& Giles, 1970)

\begin{tabular}{|c|c|c|}
\hline $\begin{array}{c}\text { Material } \\
\text { inoculated }\end{array}$ & $\begin{array}{l}\text { No. of } \\
\text { recipients }\end{array}$ & $\begin{array}{l}\text { No. of cases } \\
\text { of hepatitis }\end{array}$ \\
\hline $\begin{array}{l}\text { IH serum alone } \\
\text { IH serum + }\end{array}$ & 14 & 8 \\
\hline immunoglobulin & 10 & 0 \\
\hline $\begin{array}{l}\text { SH serum alone } \\
\text { SH serum }+\end{array}$ & 8 & 8 \\
\hline immunoglobulin & 14 & 10 \\
\hline
\end{tabular}

* IH, Infectious hepatitis; SH, serum hepatitis.

infected serum without immunoglobulin, all became infected. It is of interest that when a similar experiment in which serum from patients suffering from infectious hepatitis was mixed with immunoglobulin and given to ten children, none developed infectious hepatitis.

\section{References}

Grossman, E.B., Stewart, S.G. \& Stokes, J. JR. (1945) Post-transfusion hepatitis in battle casualties and a study of its prophylaxis by means of human immune serum globulin. Journal of the American Medical Association, 129, 991.

KrugmaN, S. (1963) The clinical use of gamma globulin. New England Journal of Medicine, 269, 195.

Krugman, S. \& Giles, J.P. (1970) Viral hepatitis: new light on an old disease. Journal of the American Medical Association, 212, 1019.

Pollock, T.M. \& ReID, D. (1969) Immunoglobulin for the prevention of infectious hepatitis in persons working overseas. Lancet, i, 281.

Public Health Laboratory Service (1968) Assessment of British gammaglobulin in preventing infectious hepatitis. British Medical Journal, 3, 451.

Stokes, J. JR. \& NeEFe, J.R. (1945) Prevention and attenuation of infectious hepatitis by gammaglobulin: preliminary note. Journal of the American Medical Association, 127, 144.

WARD, R. \& Krugman, S. (1962) Etiology, epidemiology and prevention of viral hepatitis. Progress in Medical Virology, 4, 87. 